\title{
Is appendicitis familial?
}

\author{
N ANDERSSON, H GRIFFITHS, J MURPHY, J ROLL, A SERENYI, I SWANN, \\ A COCKCROFT, J MYERS, A ST LEGER
}

British Medical fournal, 1979, 2, 697-698

\section{Summary and conclusions}

A family history of appendicectomy was sought in two groups of children admitted to Llandough Hospital over sixteen months. The study group consisted of 29 children with histologically confirmed acute appendicitis, while the control group consisted of 29 children admitted for reasons unrelated to abdominal pain. A history of appendicectomy was elicited in first-degree relatives-that is, siblings and parents of 20 of the children in the study group and of four of the controls-a statistically significant difference.

The results obtained from this study suggest that a familial predisposition to appendicitis exists.

\section{Introduction}

Acute appendicitis is the commonest surgical emergency in children, but its aetiology and pathology remain incompletely understood. Isolated families have been reported in which a strong family history exists, ${ }^{1-5}$ but so far as we are aware no controlled study has been carried out to show a family history of the condition. The notion that appendicitis is familial is not only important for understanding the aetiology of the condition but might contribute substantially to the diagnosis and thus provide an indication for early surgical intervention.

\section{Subjects and methods}

We followed up 29 children from Llandough Hospital (15 girls and 14 boys) aged 5-15 years with histologically proved acute appendicitis. This study group was extracted from pathology reports, each sex being taken consecutively. A control group of 29 children (15 girls and 14 boys) with the same mean age for each sex (boys 8.0 years, girls 7.9 years) were taken from admission books of the wards serving the same geographical population. All 58 children were Caucasians admitted to hospital during June 1977 to October 1978.

We excluded from the control group all children suffering from malignant disease, diabetes mellitus, mental retardation, and immune problems, and those receiving long-term steroid treatment; all

\footnotetext{
Department of Child Health, Welsh National School of Medicine, Llandough Hospital, near Cardiff

N ANDERSSON, MRCS, house officer

H GRIFFITHS, $M B, B S$, house officer

J MURPHY, MRCP, registrar

J ROLL, MB, CHB, senior house officer

A SERENYI, MB, BS, senior house officer

I SWANN, MRCP, senior registrar

MRC Pneumoconiosis Unit, Llandough Hospital

A COCKCROFT, MRCP, registrar

London School of Tropical Medicine and Hygiene, London

J MYERS, MB, BSC, postgraduate student

MRC Epidemiology Unit, Cardiff

A ST LEGER, MB, MSC, medical statistician
}

children who had presented with abdominal pain, on the grounds that a strong family history of appendicectomy might predispose to abdominal symptoms; and children who on follow-up were found to have had appendicectomies. The group included children admitted for elective surgical procedures, non-abdominal emergencies, and medical investigations. It was thus a mixed hospital population of children that we thought could not be distinguished from the general population from the point of view of appendicitis.

A questionnaire inquiring into the history of appendicectomy in first-, second-, and third-degree relatives was administered to the parents of both groups of children by six of us (NA, HG, JM, JR, AS, and IS). The groups were evenly allocated among the investigators, who interviewed parents either at their homes or by telephone. The questionnaire was structured so that each relative was asked about in turn and his/her age at the time of appendicectomy recorded. Pathology reports were not sought for affected relatives of either group.

\section{Results}

A family history of appendicectomy among first-degree relatives (sibling or parents, or both) was found in 20 of the 29 children in the appendicitis group and in four of the 29 controls (table I). This

TABLE I-Numbers of children in both groups with first-degree relatives who underwent appendicectomy

\begin{tabular}{ccccccc}
\hline & & $\begin{array}{c}\text { No } \\
\text { in group }\end{array}$ & $\begin{array}{c}\text { No with } \\
\text { siblings } \\
\text { affected }\end{array}$ & $\begin{array}{c}\text { No with } \\
\text { parent } \\
\text { affected }\end{array}$ & $\begin{array}{c}\text { No with } \\
\text { parent or } \\
\text { sibling affected }\end{array}$ \\
\hline Boys & $\ldots$ & $\ldots$ & 14 & $\begin{array}{c}\text { Appendicitis group } \\
2\end{array}$ & 8 & 9 \\
Girls & $\ldots$ & $\ldots$ & 15 & 4 & 9 & 11 \\
\hline Total & $\ldots$ & $\ldots$ & 29 & 6 & 17 & 20 \\
\hline Boys & $\ldots$ & $\ldots$ & 13 & Control group & & 1 \\
Girls & $\ldots$ & $\ldots$ & 16 & 1 & 3 & 3 \\
\hline Total & $\ldots$ & $\ldots$ & 29 & 2 & 3 & 4 \\
\hline
\end{tabular}

difference is unlikely to have occurred by chance $(P<0.001)$. The average number of siblings in the control group was 1.95 per case and in the appendicitis group 2.25. More-comparable numbers of second-degree relatives (grandparents, aunts, and uncles) and thirddegree relatives (cousins, second cousins, and great-grandparents) had had appendicectomies (table II). The average number of relatives asked about was 15 in the appendicitis group and 18 in the control group (range 0-56). In the control group three of the four parents

TABLE II-Numbers of children in both groups with first-, second-, and thirddegree relatives who underwent appendicectomy

\begin{tabular}{|c|c|c|c|c|c|}
\hline & \multirow{2}{*}{$\begin{array}{l}\text { No } \\
\text { in group }\end{array}$} & \multicolumn{3}{|c|}{$\begin{array}{l}\text { No with relative undergoing } \\
\text { appendicectomy: }\end{array}$} & \multirow{2}{*}{$\begin{array}{l}\text { No with } \\
\text { no known } \\
\text { affected } \\
\text { relatives }\end{array}$} \\
\hline & & $\begin{array}{l}\text { First- } \\
\text { degree } \\
\text { relative }\end{array}$ & $\begin{array}{l}\text { Second- } \\
\text { degree } \\
\text { relative }\end{array}$ & $\begin{array}{l}\text { Third- } \\
\text { degree } \\
\text { relative }\end{array}$ & \\
\hline $\begin{array}{l}\text { Boys } \\
\text { Girls }\end{array}$ & $\begin{array}{l}14 \\
15 \\
\end{array}$ & $\begin{array}{c}\text { Appen } \\
9 \\
11\end{array}$ & $\begin{array}{c}\text { is group } \\
5 \\
10\end{array}$ & $\begin{array}{l}5 \\
5\end{array}$ & $\begin{array}{l}3 \\
2\end{array}$ \\
\hline Total & 29 & 20 & 15 & 10 & 5 \\
\hline $\begin{array}{l}\text { Boys } \\
\text { Girls }\end{array}$ & $\begin{array}{l}13 \\
16\end{array}$ & $\begin{array}{l}\text { Con } \\
1 \\
3\end{array}$ & $\begin{array}{r}\text { group } \\
7 \\
5\end{array}$ & $\begin{array}{l}3 \\
3\end{array}$ & $\begin{array}{l}4 \\
6\end{array}$ \\
\hline Total & 29 & 4 & 12 & 6 & 10 \\
\hline
\end{tabular}


who had undergone appendicectomy were aged over 20 years at the time of operation. In the appendicitis group only two of the 17 parents affected were older than 20 .

\section{Discussion}

In so far as appendicectomy is related to acute appendicitis our results suggest that there is a familial predisposition to appendicitis in childhood. This might be attributed to a familial dietary factor, in particular a low-fibre diet, which could predispose to faecolith formation and obstruction of the appendix lumen. ${ }^{6}$ The geographical distribution of appendicitis in developed Western countries has been cited in support of this theory. ${ }^{8}$ In the absence of a controlled study taking account of genetic, nutritional, and geographical considerations the theory is difficult to sustain, since $40^{\circ}$ of normal appendices contain faecoliths ${ }^{9}$ compared with only $10^{\circ}{ }_{0}$ of inflamed appendices. ${ }^{6}$

Another explanation of the familial predisposition is some genetic mechanism, possibly a polygenic inheritance. This would also be supported by the geographical distribution of the condition. Inherited developmental anomalies of the anatomy of the appendix have been suggested as one possible mechanism for any familial predisposition to acute appendicitis. ${ }^{10}$
A family history of appendicectomy might provide a useful contributory indication for appendicectomy, although a negative family history would not, of course, preclude acute appendicitis.

We should like to thank Dr E R Verrier Jones, Dr E N Thompson, Dr J Sibert, Mr M Wheeler, Mr A Aubrey, and Mr H Vernon Jones, whose patients were used in this study. Thanks also go to Llandough Hospital records department for help and co-operation and to $\mathrm{Dr} R$ Seal of the pathology department for permission to use pathology records.

\section{References}

1 Van Meter, S D, Colorado Medicine, 1920, 17, 241.

2 Baker, E G S, Fournal of Heredity, 1937, 28, 187.

${ }^{3}$ Perry, T, and Keeler, C E, American fournal of Surgery, 1939, 46, 259

${ }^{4}$ Nusselt, S, Medizin Monatsschrift, 1977, 31, 232.

5 Budd, D C, and Foulty, W J, American Fournal of Surgery, 1977, 133, 670.

6 Johnson, J R, British Medical fournal, 1978, 1, 305.

' Horton, L W C, British Medical fournal, 1978, 2, 1672.

${ }^{8}$ Burkitt, D P, British fournal of Surgery, 1971, 58, 695.

${ }^{9}$ Burkitt, D P, Moolgaokar, A S, and Tovey, F I, British Medical fournal, $1979,1,620$.

${ }^{10}$ Downs, T M, Annals of Surgery, 1942, 115, 21.

(Accepted 25 fuly 1979)

\title{
Obstetric anaesthetic and analgesic services in Wales
}

\author{
BRYAN M HIBBARD, GARETH REES, MICHAEL ROSEN
}

British Medical fournal, 1979, 2, 698-700

\section{Summary and conclusions}

A survey of obstetric anaesthetic services in Wales covering 21 major units in which over 31000 deliveries take place annually showed inadequacies in staffing at consultant and resident anaesthetist level. At least 20 additional consultant sessions were required to meet the recommendations of the Association of Anaesthetists of Great Britain and Ireland.

If patients' requests for epidural analgesia are to be met some reorganisation and centralisation of facilities is needed.

\section{Introduction}

Reports on maternal deaths in England and Wales during 1952$72^{1}$ have shown that between 10 and 20 maternal deaths are associated with anaesthesia each year, while the proportion of such deaths had increased to $13.2 \%$ in the latest report (1979). From time to time obstetricians, anaesthetists, midwives, and the public express concern that facilities for obstetric anaesthesia and analgesia are inadequate. We therefore undertook a review of these services in Wales.

Welsh National School of Medicine, Heath Park, Cardiff CF4 4XN BRYAN M HIBBARD, MD, FRCOG, professor of obstetrics and gynaecology South Glamorgan Area Health Authority (Teaching) GARETH REES, MB, FFARCS, consultant anaesthetist MICHAEL ROSEN, MB, FFARCS, consultant anaesthetist

\begin{abstract}
Methods
We obtained data concerning the 20 NHS consultant units and one large general practice unit in which caesarean sections are performed. We derived the distribution of births in Wales by area from data from the Office of Population Censuses and Statistics. ${ }^{2}$ Data on regional analgesia was obtained from the Hospital Activity Analysis. ${ }^{3}$ We used data acquired personally from obstetricians and anaesthetists, based on questionnaires and visits, to provide additional information on the available staff and services and the use of regional analgesia in maternity units.
\end{abstract}

\section{Results}

Over $92.5^{\circ}$, of deliveries in Wales take place in NHS consultant units (table I). This survey therefore covered most births in Wales (over 31000 deliveries). Returns from individual units showed that about 2600 caesarean sections were performed annually.

TABLE I-Number $(\%)$ of births by place of confinement for each Area Health Authority in Wales, $1976^{2}$

\begin{tabular}{|c|c|c|c|c|c|c|}
\hline \multirow[b]{2}{*}{$\begin{array}{c}\text { Area } \\
\text { health } \\
\text { authority }\end{array}$} & \multicolumn{6}{|c|}{ Place of confinement } \\
\hline & $\begin{array}{l}\text { NHS } \\
\text { consultant } \\
\text { maternity } \\
\text { units }\end{array}$ & $\begin{array}{c}\text { NHS } \\
\text { general } \\
\text { practitioner } \\
\text { maternity } \\
\text { units }\end{array}$ & Home & $\begin{array}{l}\text { Non- } \\
\text { NHS } \\
\text { hos- } \\
\text { pitals }\end{array}$ & $\begin{array}{c}\text { Else- } \\
\text { where }\end{array}$ & Total \\
\hline Clwyd & $4265(90 \cdot 2)$ & $377(8 \cdot 0)$ & $70(1 \cdot 5)$ & 1 & 18 & 4731 \\
\hline Dyfed & $3335(92 \cdot 2)$ & $210(5 \cdot 8)$ & $64(1 \cdot 8)$ & & 17 & 3626 \\
\hline Gwent & $4746(90.5)$ & $402(7 \cdot 7)$ & $88(1.7)$ & 2 & 6 & 5244 \\
\hline Gwynedd & $2505(95 \cdot 7)$ & $88(3.4)$ & $13(0.5)$ & 1 & 10 & 261 \\
\hline Mid Glamorgan & $6386(93.5)$ & $247(3 \cdot 6)$ & $185(2 \cdot 7)$ & & 12 & 683 \\
\hline Powys & $614(50.9)$ & $574(47 \cdot 6)$ & $13(1 \cdot 1)$ & & 5 & 120 \\
\hline South Glamorgan & $4676(98.9)$ & $12(0 \cdot 25)$ & $39(0.8)$ & 1 & 2 & 4730 \\
\hline West Glamorgan & $4341(98.6)$ & $12(0.27)$ & $49(1 \cdot 1)$ & & 2 & 4404 \\
\hline Wales & $30868(92 \cdot 5)$ & $1922(5 \cdot 8)$ & $521(1 \cdot 6)$ & 5 & 72 & 33388 \\
\hline
\end{tabular}

